\title{
Tiny Symbols Tell Big Stories Naming and Concealing Masturbation in Diaries (1650-1940)
}

\section{Leonieke Vermeer}

University of Groningen, The Netherlands

\section{ABSTRACT IN ENGLISH}

Symbols, encryptions and codes are a way to hide sensitive or highly personal content in diaries. This kind of private language is an important feature of diary practise, regardless of time and place, but it has barely been studied yet. This article highlights symbols that designate masturbation in diaries of the mid- $17^{\text {th }}$ century until the first half of the $20^{\text {th }}$ century. These symbols are interpreted not as 'silence,' but as disguising, narrative strategies. They form an integral part of the text and should be studied as such. The central question is how authors by employing disguising strategies (such as symbols) in diaries position themselves within and against public discourse on masturbation. The main body of sources consists of six diaries from different national contexts. The discourse against masturbation which developed from the beginning of the $18^{\text {th }}$ century was an international (Western) affair. In medical treatises and pedagogical manuals for parents, masturbation became a 'total illness': a lifethreatening activity that would lead to near-certain (and gruesome) death. Diary writing functioned as a medium to register and control this secret vice but the diaries also show ways to change or resist the dominant discourse. The symbols for masturbation reflect some crucial aspects of diary writing: the diary as a memory device and a medium of registry and control of bodily processes, in which private experience is connected to public discourse.

\section{ABSTRACT IN DUTCH}

Symbolen, geheimschrift en codes in dagboeken zijn een manier om gevoelige, intieme informatie te verhullen. Dit soort persoonlijk taalgebruik is een 
belangrijk kenmerk van dagboeken, hoe verschillend ook in tijd en ruimte, maar het is tot dusver nauwelijks bestudeerd. Dit artikel focust op symbolen die naar masturbatie verwijzen in dagboeken van het midden van de zeventiende tot de eerste helft van de twintigste eeuw. Deze symbolen worden niet als 'stilte' opgevat, maar als verhullende, naratieve strategieën. Ze vormen een integraal onderdeel van de tekst en dienen ook als zodanig bestudeerd te worden. De centrale vraag is hoe auteurs door middel van verhullende strategieën (zoals symbolen) in dagboeken discoursen over masturbatie verwerken. De belangrijkste bronnen zijn zes dagboeken uit verschillende landen. Het antimasturbatie discours dat zich ontwikkelde vanaf het begin van de achttiende eeuw was een internationale (westerse) kwestie. In medische en pedagogische traktaten werd masturbatie gezien als een 'totale ziekte': een levensbedreigende gewoonte die tot allerlei geestelijke en lichamelijke afwijkingen met zeer waarschijnlijk een fatale afloop zou leiden. Het dagboek werd als middel gezien om deze geheime zonde onder controle te krijgen. Maar de dagboeken tonen ook manieren waarop het dominante discours werd weersproken of veranderd. De symbolen voor masturbatie laten enkele cruciale aspecten van het dagboek als genre zien: de herinneringsfunctie en een middel tot registratie en controle van lichamelijke processen, waarin persoonlijke beleving en publieke discoursen met elkaar verbonden zijn.

Keywords: diary writing, symbols, masturbation, discourse, narrative strategies

\section{INTRODUCTION}

Mistakenly I have put myself down because of fear for loss of sperm I counted for 02-03 in total 58.

Our contrary suggestion! ${ }^{1}$

This diary entry was written by the Dutch law student Leo Polak on 8 January 1903. Later in life Polak would become a renowned philosopher and criminal law theorist. ${ }^{2}$ What did Polak count exactly in his diary? And why was he afraid for "loss of sperm"? The little crosses that appear regularly in his diary, mostly before a date, give more insight. Polak is one of the diarists that counted his ejaculations by way of a symbol in his journal. The use of symbols and other forms of "private language" is a salient feature of diary practise, regardless of time and place, but it has barely been studied yet. ${ }^{3}$ How should one analyse these symbols? As absence of language, gaps or silences, which are often signalled by diary scholars, or as a different kind of language?

"Many diaries, to be sure, are eloquent only in what they omit" (Gay $1995,336)$. In his historical study of the intimate life of the $19^{\text {th }}$ century 
bourgeoisie, Peter Gay showed the richness of diaries as a source, but he also pointed at a feature that strikes everyone who does diary research: the frequent silences one encounters. Historian Roy Porter argued that "the first-hand written record [...] is largely silent—and where it is eloquent, it is probably unrepresentative" $(1991,210)$. In his remarkable study on the diaries of adolescent French girls, Philippe Lejeune has also pointed at the importance of gaps: "A girl could keep a diary, without any interruption, between the ages of eight and seventeen, without mentioning at all the transformations brought about by puberty. The expression of feelings and emotions is usually extremely reserved" $(2009,132)$. Although the importance of silences is stressed by most autobiography and diary scholars, they have hardly been the focus of research.

Gay, Porter and Lejeune point at gaps, silences, implicit meanings; non-appearance of information you would expect. The crosses of Polak, however, are there. They are not an absence of narrative, but an element in narrative. As Susan Sontag rightly stated: "Silence remains, inescapably, a form of speech [...]" $(1969,11)$. Therefore, I interpret symbols as disguising strategies: narrative strategies and techniques that writers employ to tell stories. These strategies and stories can only be understood in their context; the immediate context of the text, but also in relation to other texts and public discourse. ${ }^{4}$ Besides symbols, disguising strategies to hide sensitive or highly personal content can consist of: euphemisms, abbreviations, secret language, foreign language, mirror writing, anagrams, etc.

The study of disguising strategies in diaries can provide us with information on a subject for which source material is rare: bodily and sexual experiences. In this respect diaries can tell stories about a range of topics, for example health and illness, menstruation, drug addiction, sexuality. In this article, I will focus on disguising strategies for masturbation, because this topic particularly brings relevant historical and methodological issues to the fore, especially the complex relationship between experience and discourse. Experience is discursive. Eating, sleeping, bleeding, masturbating, having sex, giving birth, suffering, dying; bodily experience is more than-and often precedes-the expression of it in language. But making meaning of these experiences in a diary, or in other forms, is shaped by the discursive context (Smith and Watson 2010, 32; Piller 2015, 82). My central question is how authors, by employing disguising strategies (such as symbols) in diaries position themselves within and against public discourse on masturbation.

The discourse against masturbation which developed from the beginning of the $18^{\text {th }}$ century was an international affair. Important publications in this respect, like the anonymously authored Onania and Tissot's 
L'Onanisme were translated into several languages. It, therefore, makes sense to study this topic in an international context and to use sources in different languages. Furthermore, encryption offers an outstanding opportunity to study diaries transnationally, because the symbols are not bound to a certain language - similar to emoticons today. On the contrary, as I will show, some diarists found inspiration in their use of symbols from other famous, international examples.

I have used sources from my research on illness experiences in $19^{\text {th }}$ century self-narratives (Vermeer 2015). But I also studied international sources on the basis of existing historiography. This resulted in a corpus of six diaries in which symbols are used for masturbation, written by William Drummond, Robert Hooke, Johann Rudolf Huber, Alexander van Goltstein, Anne Lister and Leo Polak. In order to add context and compare the findings, I will also mention some additional self-narratives (diaries and autobiograpies). ${ }^{5}$ The six main diaries (of five men and one woman; two English, two Dutch, one Scot and one Swiss) cover the mid$17^{\text {th }}$ century to the first half of the $20^{\text {th }}$ century. This period encompasses the century before the origin of the anti-masturbation discourse $\left(17^{\text {th }}\right.$ century), the high days ( $18^{\text {th }}$ and $19^{\text {th }}$ centuries $)$ and the fade out $\left(20^{\text {th }}\right.$ century). Although I am aware of the fact that the diarists and their historical contexts differ in various ways, the aim is to make clear that their common denominator-the disguising strategies for masturbation-justifies their comparison and adds an analytical value to the study of bodily experiences and discourses in diaries.

Before I come to the case study of masturbation, I will give a short overview of the historiography and theory on encryptions and the (gendered) body in self-narratives.

\section{DISGUISING STRATEGIES AND THE AUTOBIOGRAPHICAL BODY}

The German computer scientist and expert on encryption technology, Klaus Schmeh, has made a list of encrypted books which contains 41 entries from the $15^{\text {th }}$ to the $21^{\text {st }}$ century. Fourteen entries are diaries, which make it the largest type of encrypted book. In his article in the journal Cryptologia (2015) Schmeh wonders if there are actually so many encrypted diaries or whether encrypted diaries are discovered more often than other encrypted books. He does not cover encrypted diaries in detail in his article and states that a separate work about this topic would be justified (Schmeh 2015, 357). Schmeh's interest-and this also counts for the journal Cryptologia as a whole-is foremost the encryption (and decoding) itself. The function in its historical time and place seems 
less of a concern. For me, as a cultural and literary historian, encryptions should be read as narrative strategies, which point to a pivotal aspect of the current study of life writing: the way in which a self represents itself and constructs identities, between private and public persona, marked by multiple discourses (Burke 2011).

In his comprehensive history of European diaries, Gustav René Hocke distinguishes two main types of "Verbergen" ("hiding") in diaries: erotical and political. Both of these originate "from the experience of confinement both in private as in public." "His analysis of "hiding," rooted in a psychoanalytic approach, is limited in two ways. Although Hocke's study is based on 500 diaries from 4 centuries, the ones with literary merits are privileged in his analysis. ${ }^{7}$ His examples are taken from the autobiographical canon of famous men, such as Boswell, Goethe, Tolstoy, Camus and Orwell. By doing this, a large part of diary writing as a cultural practise, performed by "ordinary" men and women is neglected. I prefer the more inclusive approach of Lejeune and other diary scholars, in which a whole range of diaristic texts is studied in their "heteroglossic diversity" (Millim 2010, 1). Also, Hocke's concept of the typical diary is ahistorical (Mascuch, Dekker and Baggerman 2016, 49). He focuses on diary writing as a subjective expression and regards the "journal intime" as prototypical: "In diaries that "tell everything," the "last" intimacies are hidden in a more or less inventive way." So, in Hocke's view there is a paradox, because diaries try to be open and truthful and simultaneously hide the most intimate information (Hocke 1991, 162-172). This paradox, however, is based on too narrow a view of the diaristic genre, which is not justified by current research.

Recent studies have shown that the prototypical "journal intime"-the diary as an intimate, imaginative best friend, hidden away from everyone, often with a lock on it - is actually not the most common diary, certainly not before 1900. The Dutch historians Rudolf Dekker and Arianne Baggerman have argued in their book Controlling time and shaping the self (2011), that most diaries were not intimate, but gave more information about the weather and social visits. Emotions and self-reflection were the exception, not the rule. The primary function of these diaries was to "control time" in a rapidly changing society (Baggerman 2011). The prototypical, personal diary with a lock on it, is a minority. In the inventory of Dutch $19^{\text {th }}$ century ego-documents (3472 manuscripts) I have found only two diaries with a lock on them. ${ }^{9}$ Numbers from the Sammlung Frauennachlässe (collection of women testimonies) show that only eight of the 747 diaries that have been handed down from the $20^{\text {th }}$ century, had a lock on them. Even if diaries had a lock, the diarist probably still had potential readers (real or imaginary) in mind. Diaries were often meant as a method of communication; they were read by others, as we can infer from comments in the 
margins. ${ }^{10}$ This is important to keep in mind when analysing disguising strategies: "A code both presupposes and contrives a reader" (Rowanchild $2000,205)$. Disguising strategies simultaneously conceal and reveal something for someone.

Disguising strategies, as argued above, can give an insight into the way the self represents itself and constructs identities. Identity resides for an important part in the body or bodily practises. The role of the body has only recently gained a presence in autobiography studies. It did not fit in with the image of the "proper" autobiographical self: a unified, coherent, individual and disembodied self (Kurvet-Käosaar 2006, 40). Autobiography scholars such as Sidonie Smith and Leena Kurvet-Käosaar have shown that the body is indeed very present in autobiographical texts, even when it is erased through self-censoring (Smith 1994; Kurvet-Käosaar 2006).

Connected to the mind/body dichotomy is the gender-biased binary opposition (and hierarchy) between autobiography as a male form and diary as a female form. ${ }^{11}$ But the diary is not an inherently feminine mode of writing, nor is it uniquely suited for women's lives, especially when we look further back (Holmes 2011, 171). In the Dutch Diary Archive, with a collection of diaries from the $19^{\text {th }}$ century until the present day, men's and women's diaries seem to be equally represented. ${ }^{12}$ However, if we go further back in time, to the Dutch inventory of "ego-documents" (which contains not only diaries, but also other self-narratives, such as autobiographies, memoirs and travel journals from the period 1500-1814) only $10 \%$ of the self-narratives that have been handed down were written by women. ${ }^{13}$ Still, the explanation of this small percentage-namely that less women were able to write, even among the bourgeoisie (Lindeman 2016, 22) - does not tell the whole story. It also has to do with the difference in status between men's and women's autobiographies and the tension between authorship and the female ideal as housewives and mothers (Magnússon 2013; Huisman 2008, 210). This explanation is valid for published autobiographies, but if, and in what way, this applies for diaries as well, with regard to the influence of (gendered) archival practises, has barely been studied yet (cf. Lejeune 2009, 307; Hallgrimsdottir 2013).

In conclusion, both men and women wrote diaries and bodily experiences were present (and erased) in diaries by both sexes. But there were gendered differences with regard to the discourse against masturbation and the ways diarists revealed and disguised it, as will be shown.

\section{THE DISCOURSE AGAINST MASTURBATION}

Masturbation is "the world's most common sexual practise," but it has barely made a mark on the historical record (Laqueur 2003; Toulalan 
and Fisher 2013, 266). In the $18^{\text {th }}$ and $19^{\text {th }}$ centuries much was written against masturbation, but it is harder to find information on the practise itself. Encryptions in diaries form interesting, but neglected source material in this respect. These symbols—crosses, stars, dashes-can only be understood in relation to the anti-masturbation discourse. Masturbation intensely bothered both religious and medical authorities from 1750 until World War II. A private matter has probably never been made more public.

Before the $18^{\text {th }}$ century masturbation was sometimes seen as benign or even salutary, while others condemned it for moral, not medical, reasons (Stolberg 2000, 43-45; Laqueur 2003, 83-183). In the Christan sexual norm, onanism was sinful, embarrassing, not to be talked about, but it was also seen as an aspect of life and taken for granted. The general attitude was relatively relaxed (Stevenson 2000, 226). The starting point of the anti-masturbation campaign was the anonymous pamphlet Onania; or, The Heinous Sin of Self-Pollution, initially distributed in London "in or around 1712." ${ }^{14}$ It prompted numerous imitators, self-help pamphlets and patent medicines, culminating with its medical legitimisation thanks to the publication of L'Onanisme ou dissertation physique sur les maladies produites par la masturbation (1760) by the celebrated Swiss physician Samuel Tissot. ${ }^{15}$ The augmented edition (1764) of this work was followed by 64 reprints and translated into several languages. The period 1790-1805 was the peak period for literature against onanism, but the "immense jabbering," to use Foucault's phrase, did not stop in the $19^{\text {th }}$ century (Foucault 2003, 233, 259, n.6; Hekma 1988, 234-237, 252-254). In medical treatises by accredited doctors and pedagogical manuals for parents, masturbation became a "total illness": a life-threatening activity that debilitated the body and mind, leading to any variety of diseases and mental disorders and ending in near-certain (and gruesome) death (Foucault 2003, 239).

"Masturbation" is a modern, medical term, denoting: "to touch or rub your sexual organs in order to give yourself sexual pleasure" (Cambridge English Dictionary). The word 'masturbation' occurs for the first time in 1706 (Laqueur 2003, 424). The Dutch equivalent "masturbatie" was used for the first time in $1847 .{ }^{16}$ The terms "onanie" (onanism) and "zelfbevlekking" (self-defilement or -pollution) were more common terms in the $19^{\text {th }}$ century. ${ }^{17}$ Onanism is derived from the biblical character Onan, who withdrew before his orgasm and "spilled his seed on the ground." 18 In scientific publications the terms "autoeroticism" or "autoerotic practises" are sometimes used, rather than masturbation, to denote non- (or not uniquely) genital-based sexual arousal. ${ }^{19}$

There have been several explanations for the campaign against masturbation in the $18^{\text {th }}$ and $19^{\text {th }}$ centuries. ${ }^{20}$ Historians had to come to terms with the simultaneity of the Enlightenment and anti-masturbation 
literature. Was it an aberration, a wrong track in the progress of reason? Or was it an essential part of the pedagogical programme of the Enlightenment? This last option has been convincingly justified, albeit with different accents. Although both Thomas Laqueur and Michel Foucault consider the anti-masturbation campaign as a quintessentially modern phenomenon, they offer different explanations for its cause. Foucault presents the campaign as a manifestation of "bio-power" through the medical and pedagogical discourse and control of childhood sexuality. ${ }^{21}$ Laqueur perceives masturbation as the evil twin of modern commercial society, in which private gain, solitude and the pleasures of imagination are important. "The secret sin" was the negation of "the public sphere," it was "the dark underbelly of Civil Society." The solipsistic pleasure of masturbation contradicted the education of morally self-governing, rational human beings and therefore was seen as a threat to society at large (Laqueur 2003, 247-358).

My aim is not to settle this discussion, but to offer a different perspective: the masturbator and his or her diary. Although the medical and pedagogical treatises contain a lot of testimonies and letters by "sinners" or "sufferers" themselves—offered as frightening examples—-these are still part of the "medical gaze." Self-narratives, such as diaries, have hardly been taken into account in this discussion, mostly as single case studies. ${ }^{22}$ In a way this is understandable, because there are not many self-narratives in which masturbation is mentioned, at least not very explicitly. But the examples that have been found are, therefore, even more remarkable.

\section{(DE)CODING MASTURBATION IN DIARIES}

With the mentioned chronology in mind, it is telling to see that in diaries from the century before 1712 - the starting point of the anti-masturbation campaign-masturbation does not yet have a discomforting connotation. By the late $17^{\text {th }}$ century, masturbation might still be unmentionable in public, but it was being written about in private. This becomes clear from a few references in the diaries of Puritan Protestants, who confessed to themselves in detail about individual sins (Stevenson 2000, 229-230). The earliest known individual who recorded the occasions on which he masturbated, was the young Scottish gentleman William Drummond. He documented this information in his private diary between 1657 and 1659 and coded this so successfully that the diary's editor failed to understand what was meant. He used the term "fatal" for masturbation and recorded this 62 times on 38 days, plus two occasions on which no number is specified ("all night fattall" and "fattall most grivously"). David Stevenson 
argues convincingly that Drummond kept a record and used the term "fatal," not because he condemned the act of masturbation itself, but because ancient medical tradition (humoral theory) warned against the excessive loss of semen, which would be physically debilitating. But his attitude against masturbation was quite casual and relaxed (Stevenson 2000, 224, 235).

This stance could also be argued for the most famous early-modern example: the diary of Samuel Pepys. The episode on his arousal on 9 February 1668 by the French pornographic book, L'Escole des filles and his burning of the book thereafter, is often quoted. ${ }^{23}$ Full sexual intercourse occurs rarely in his diary, but Pepys reports masturbating regularly, both in private and in public. ${ }^{24}$ His sexual life is "self-absorbed," founded in the imagination and stimulated by the reading of erotic literature; exactly the dangers which doctors, philosophers and moralists would warn against in later centuries. Allthough Pepys sometimes feels ashamed after having masturbated, there is no sign that he regarded it as a sin or an illness. On the contrary, it kept him out of the troubles which sexual intercourse with his wife or other partners brought to him. It was part of quotidian reality (Grantham Turner 2003, 226-240; Laqueur 2003, 180-182). Pepys's use of disguising strategies has been called a "complex, teasing game of secrecy and display." His entire diary is written in shorthand, but in the abovementioned episode of 1668 in particular the sexual key words ("L'escholle des Filles" and "decharger") stand out, because they are written in longhand. He used encryptions, euphemisms, "Franco-Spanglish" (una vez to decharger) and added nonsense-syllables to certain words (Grantham Turner 2003 , 4) but he did not use a repetitive symbol for masturbation.

The first diary, to my knowledge, with recurring symbols for sexual activity is written by the English physicist Robert Hooke. ${ }^{25}$ In his "memoranda" (1672 to 1683), written in an abrupt and factual style, he records weather variations and astronomical observations, alongside records of his daily activities. His diary began as a philosophical exercise, but it soon became more private, as is evident in entries concerning his health and his immediate household (Mulligan 1996; Henderson 2007). In this respect, he also mentions his ejaculations, for which he uses a symbol. Hooke's first editors in 1935 interpreted this symbol as "Pisces, the twelfth sign of the Zodiac. Used by Hooke to indicate orgasm, probably because of the association of Venus and Cupid in the legendary origin of the symbol" (cit. Henderson 2007, 167, n. 28). Hooke was never married, but he had several relationships. He used the "Pisces"-symbol 44 times in his diary, indicating sexual activity, both with or without women. An example of the first on 28 October 1672 with Nell, one of his servants and mistresses: "played with Nell — $¥$. hurt small of back.” An example of the 
latter on 25 December 1674: "Went late to bed. ¥ in sleep sweat much and disturbed." On 19 June 1673 two symbols appear: "made wormwood wine. $¥ ¥ ”$ (Figure 1). ${ }^{26}$

The Pisces symbol was just one of the many symbols and abbreviations Hooke used in his diary to denote repeated names, frequent occurrences, chemical substances and astronomical bodies (Mulligan 1996, 332). Whereas the first editors denote the symbol as "orgasm," in a recent edition of the diary the term "ejaculation" is deemed more appropriate, because Hooke presumably recorded this as a result of his ongoing appraisal of his own health, rather than as a record of his sexual activity (Henderson 2007, 129-175). Hooke's diary writing was part of his work as a scientist. He examined his daily behaviour just like the natural phenomena, by experiment and observation (Mulligan 1996, 311-342). So, by denoting his ejaculations with a symbol his aim was not so much to disguise the sinfulness of the action, but to record repetitive information in a short, practical and scientific way.

A century later the connotation of masturbation-and of the symbols used to denote it—changed dramatically, when it became a "total illness." The pedagogical and medical discourse against masturbation was especially aimed at the younger generation. It was no coincidence that in this same period, the end of the $18^{\text {th }}$ century, the first diaries by children and adolescents were written. Both were aspects of the same enlightened, bourgeois canon concerned with health, moral behaviour and the reform of children's education. Parents encouraged their children to keep a diary, which should help to improve their conduct. These diaries were not private; they were read by the parents and by others. ${ }^{27}$

There have been a few diaries handed down in which male adolescents graphically encoded masturbation. Gudrun Piller has extensively analysed the diary (1783-1784) of the 17/18 year-old Johann Rudolf Huber of Basel (Piller 2007, 174-197). His diary develops from "a religious examination of conscience and a refinement of morals" to "a location of permanent awareness about the body and a medium of registry and control of physical processes, such as sleep, nutrition, excretion, movement and sexuality" (Piller 2015, 85). Huber reads the literature from the bourgeois canon; his diary is permeated by the pedagogical-medical discourse of controlling corporeality and sexuality. This becomes particularly clear from the encrypted parts in his diary: "Today I first got up before 8 o'clock ---+ n.g.m.fl. $----!-!--<\mathrm{xxx}>-$." 28 Or on 3 December 1783: "Had to dress myself a bit so that I could accompany Mama across the Rhine. And then it happened again ++!! repulsive !! — — ." ${ }^{29}$ There are many places were Huber switches to this "reduced character set," based on only a few symbols: dashes, quotation marks and 


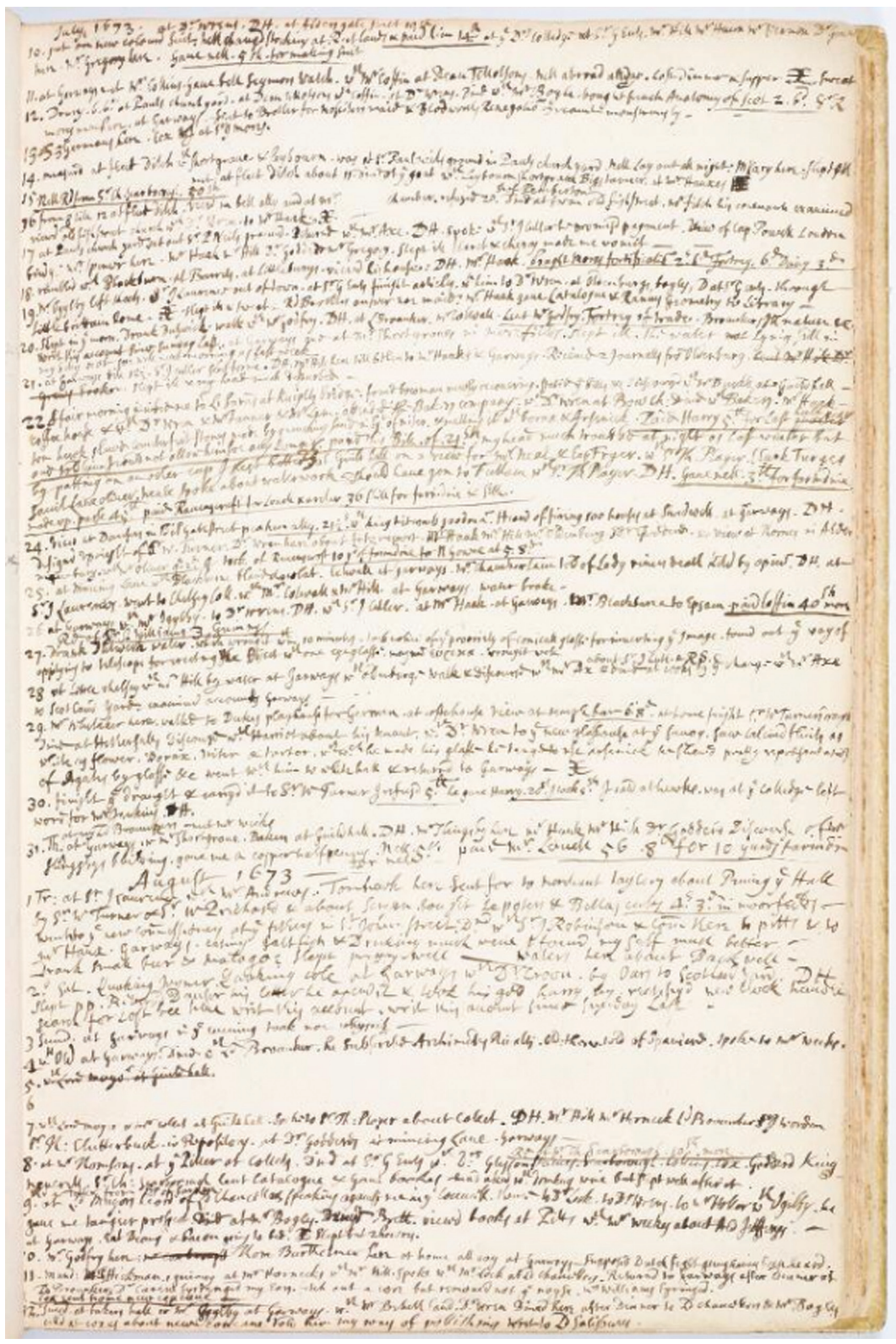

Figure 1 Sample of Robert Hooke's diary (July 1673) with the "Pisces"-symbol (11, 19, 29 July and 9 August). Diary Robert Hooke, kept from 10 March 1671/2 to 16 May 1683, Collection Robert Hooke, London Metropolitan Archives, ref. nr. MS 01758, 1666-1683. 
a few exclamations such as Pfui, Ach or Weh. Although the author does not provide an explicit key to the puzzle, it is clear that these encrypted parts are a sign of masturbation. Although Piller initially refers to these symbols as silence and the absence of language, she also considers the dilemma of both naming and concealing masturbation (2015, 87-88). One of Huber's last entries indicate that the written self-observations did not seem to help: "[...] then + !!!! — — almost a half year-woe! woe! I straightened my sheets." ${ }^{30}$

While Huber inserts crosses and thus symbolically refers to the sinfulness of the action, a contemporary of his, the young Dutch nobleman Alexander Van Goltstein, uses another symbol: a star. These stars appear regularly between two dates, referring to nocturnal activity. Van Goltstein's diary (1801-1808) is one of the earliest examples of a "journal intime." His opening sentence was: "Purpose: to make a diary of the heart" (cit. Dekker 2000, 51-52). On 9 April 1807 he compiled a list of bad traits; "onanie" (onanism) is one of them. He also regularly uses cryptic phrases, such as his "vice," his "lively imagination" that he could not keep under control, "the dangers of loneliness and the night," and "a passion [...] that deprives my health." These remarks help to explain that the stars that appear regularly between two dates refer to masturbation (Dekker 2000, 56; Van Goltstein 1994, 38). In his diet and other habits we can detect the preventive measures from the anti-masturbation literature: not lying in bed too long in the morning, a sober diet, drinking milk and the dangers of reading on a too lively imagination. ${ }^{31}$ Van Goltstein likely took this idea of graphically encoding sins from the autobiography of Benjamin Franklin, an important role model for him (Dekker 2000, 56; Van Goltstein 1994, 32-33). But this type of disguising strategy can also be found in the writings of other famous authors, for instance, in the diaries of Johann Kaspar Lavater, Victor Hugo and Georg Christoph Lichtenberg (Piller 2015, 88; Schneider 1991, 59-63; Etter 1954).

So far, only men's diaries have been addressed. How can we compare these to women's diaries? Onania was aimed at readers of both sexes, as is clear from the first sentence: "Self-polution is that unnatural practise by which persons of either sex may defile their own bodies" $(1724,1)$. But according to Piller, and others, the dangers of masturbation were firstly concerned with the economy of the male body. Women were addressed less extensively-Piller only mentions one self-narrative of a woman, Anna Katharina Vonder Mühll-Ryhiner of Basel, instructing her 6 and 7 year-old daughters in her autobiography from 1790 (Piller 2015, 90-91). A Dutch overview of the anti-masturbation campaign does not address the gender aspect explicitly, but only refers to the implications for boys and male adolescents, as part 
of the related fear for sodomy and homosexuality (Hekma 1988, 232-254). Conversely, Laqueur stresses that masturbation was perceived as a danger, both for men and women, boys and girls. He mentions Tissot and others, maintaining that onanism was even worse in women; not because of its effects on the body - these were devastating for both men and women—but with regard to their appropriate social role as wives and mothers. Onanism was a rejection of proper social conduct and the normative sexual order (Laqueur 2003, 260-261, 372). Could that be the reason that there is no female equivalent of the diaries of Huber and Goltstein? Did women conceal this sexual practise-instead of disguising it with a symbol-because it did not fit in with their proper, social role? Lejeune's study of 96 French diaries of young girls, which I have mentioned before, seems to support this conclusion: "these diaries, in which sometimes the writer declares that she will 'confide everything to her little notebook' appear to be extremely selfcensored. All that pertains to the body, to sexuality, remains outside the scope of the diary" (Lejeune 2009, 131-132).

A Dutch diary that forms a perfect example of this self-censoring trait, is the diary of Caroline van Loon, who seemed to have been totally innocent in sexual matters until her wedding day (Mathijsen 2003, 21-22). Her diary (1855-1857) was read (and checked) by her fiancée, Maurits van Lennep, who put remarks in the margins. The diary must have had covered parts, which possibly contained sensuous information, as one of Maurits's remarks in her diary suggests: "all your letters and journals with your longing to marry and with the covered passage of your burning love for me." ${ }^{2}$ Maybe Caroline concealed some passages, because she feared that her mother, who disapproved of Maurits as suitor, would read her diary. As a husband, later in life, Maurits tries to understand the "neurotic" moods of his wife and looks back on this episode in his diary. He writes that "gullible" Lore (his nickname for her) was informed by her sisters on the wedding day about the painful, cruel and humiliating torture that she would have to endure in the night to come. Caroline got very upset and almost wanted to cancel the wedding. However, they got married and 9 months and 4 days later their first son, Hendrik, was born (Mathijsen 2003, 21-22). But Caroline's diary is silent-or self-censored-about these sexual matters.

Still, Peter Gay has shown that there were exceptions to the restrained passion in female self-narratives, for example, the American editor and writer Mabel Loomis Todd, who wrote about her sexual experiences with her husband and other men in her diary (1879-1931), even showing entries for her orgasms, numbering them in sequence through each year. She used symbols in the margins for her menstrual cycle and for intercourse ("-"), in order to prevent conception (Gay 1984, 71-108; 
Gay 1995, 343; Longsworth, Dickinson and Loomis Todd 180; Brodie 2001, 45-46).

However, I only know one example of a woman's diary in which masturbation is mentioned, both explicitly and by way of a symbol: the diary of Anne Lister (1791-1840), a Yorkshire gentlewoman. ${ }^{33}$ As an heiress and landowner she was financially independent and was able to practise energetic and passionate sexual relations with women, under the cover of the prevailing culture of "romantic friendship." She was able to educate herself in the classics and mathematics. Her extensive diary contains four million words in 26 books, in very tiny handwriting. Most of the diary is written in "plainhand," one-sixth is written in "crypthand." ${ }^{4}$ She expressed her love for women explicitly in a passage written in crypthand: "I love and only love the fairer sex and thus, beloved by them in turn my heart revolts from any other love but theirs" (29 January 1821, Lister 2010, 161).

Lister developed a code so she might write of her affairs with women in secret. The code was a secret alphabet based on Greek letters and algebraic symbols. She started to use it in love letters to her first girlfriends. Most of the coded parts are on her intimate feelings and detailed descriptions of her love affairs. Other ways of concealing are the euphemisms, for example "kiss" for the sexual act. ${ }^{35}$ She observes that "writing my journal has amused me and done me good. I seemed to have opened my heart to an old friend. I can tell my journal what I can tell no one else" (30 August 1823). Still, the diary is not as private as one might think. Women's diary-writing at this time may have been a private act, but its purpose was a "private showing of self" (Delafield 2009, 35; Bloom 1996). The code both presupposes and contrives a reader (Rowanchild 2000, 205). A code draws attention to the secrets it supposedly conceals. The diary was "semi-public." Lister was annoyed when one of her lovers mentioned her "peculiar hand-writing" at a teaparty, but she shared it with a range of lovers of widely varying degrees of intimacy. Several female diarists of her time used codes and the secrecy and authorised reading became a feature of the fictional diary of the 1840s (Delafield 2009, 35-36).

The little " $x$ " or "+" symbols in the journal margins have not been the primary focus of existing studies on Anne Lister. Liddington has observed that the plus sign ("+") in the journal entries had a double meaning: it indicates her timely masterbatory practises and her autodidacticism. This last aspect concerns the "+" sign as a literary and language marker (Lister and Liddington 1998, 62, 264). This sign not only appears in the journal margins, but also in the separate index in which Lister summarised the journal entries in a highly sophisticated way. If the "+" sign appears in the index in combination with the " $\$$ '-sign, it indicates that the purpose and content of the material is of a sexual or literary nature (Orr 2006, 80-90) (Figure 2). 

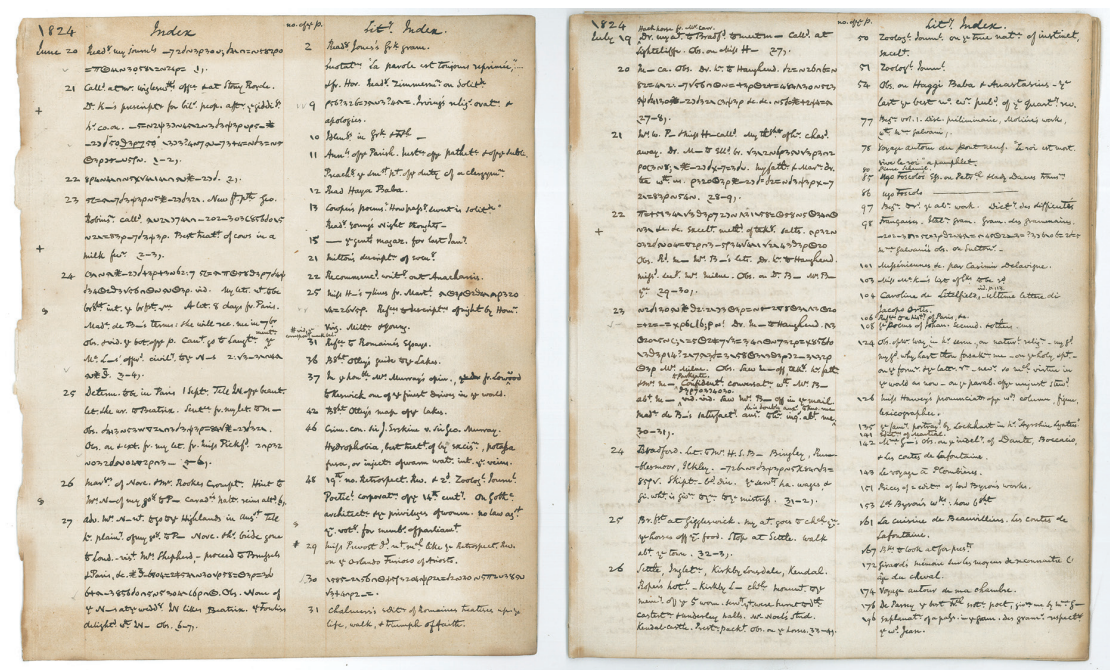

Figure 2 Sample of the literary index of Anne Lister's diary with the "+" and the "§" sign. West Yorkshire Archive Service, Calderdale, ref. nr. SH: 7/ML/E/8.

Neither the symbols nor the indices are included in the edited version of the journal (Lister 2010). Helena Whitbread, who decoded and published the diaries, confirms in a recent publication that the " $x$ " and " + " sign indicate autoerotic practises as well as erotic reading sessions. Sometimes these symbols in the margins of certain entries are followed by the coded comment "Incurred a cross". The symbol and the terminology ("incurred a cross") signify the quasi-religious and penitential meaning-she regularly prayed to God for the willpower to resist such sexual indulgences (Whitbread/Holme 2016, 45) (Figure 3). ${ }^{36}$

There are several similarities with other (male) diarists. Firstly, the use of little crosses to designate autoerotic practises. Secondly, the importance of reading and the imagination, which also played a role in the solitary sexual acts of Pepys and Goltstein. Thirdly, the term "incurred" is telling; as if she regarded it as an injury or illness-a view with which the medical anti-masturbation discourse of her time clearly agrees. The quote "escaped from +" also suggests her negative opinion about masturbation. This can also be inferred from another entry. In an excerpt written in "crypthand," Lister explicitly refers to onanism in a negative way. It is an account of a conversation with Miss Pickford, with whom Lister had a "strong, platonic friendship." Lister tried to convince Miss Pickford that relationships with women were better than "onanism": "This [onanism] is surely comparatively 


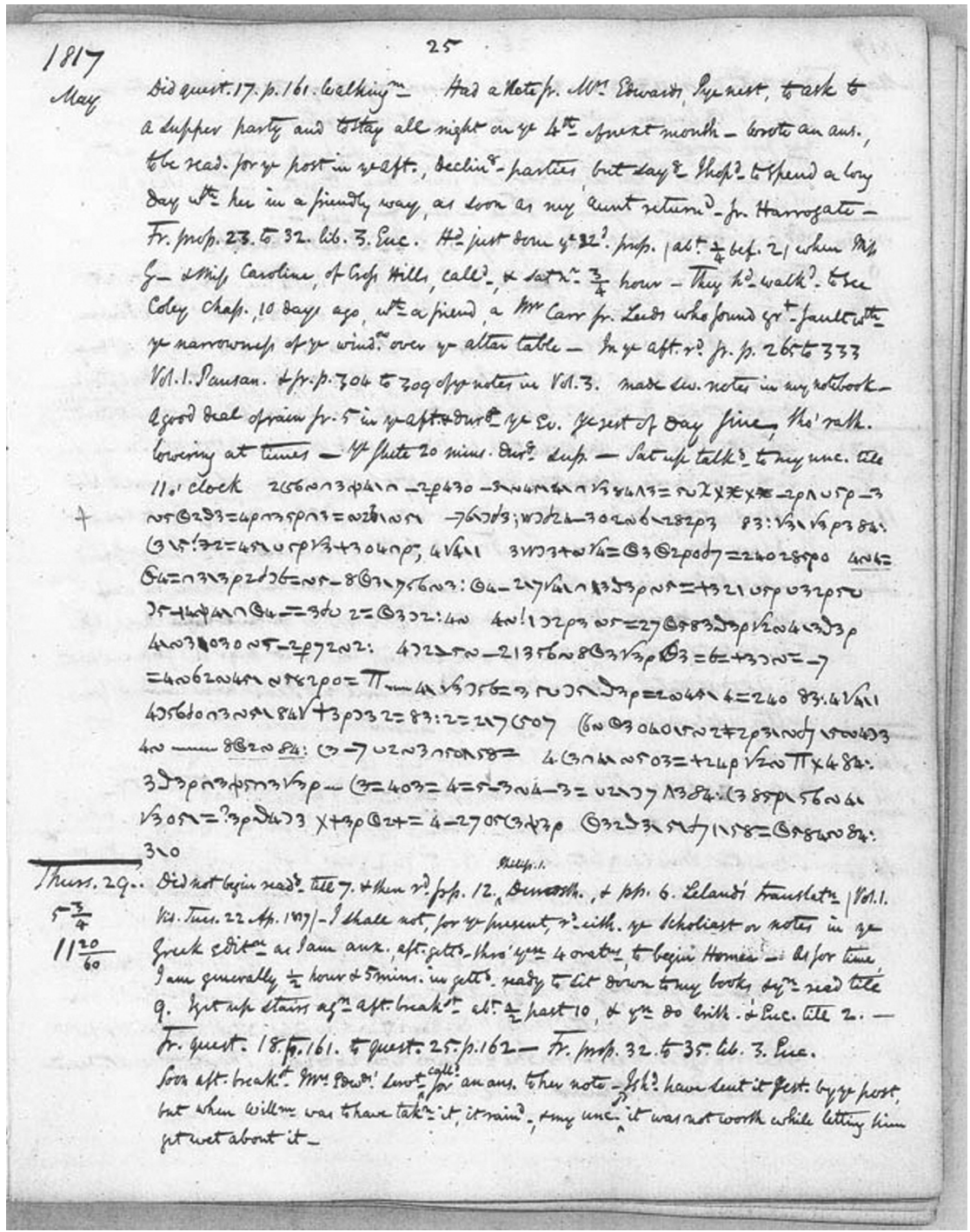

Figure 3 Sample of Anne Lister's diary with a little “+” sign in the margins (May 1817). West Yorkshire Archive Service, Calderdale, ref. nr. SH: 7/ML/E/1.

unpardonable. There is no mutual affection to excuse it" (Lister 2010, 296). However, the tiny crosses in the margins of her diary seem to indicate that her condemnation of masturbation was more rhetoric than practise. 
In men's diaries in the $19^{\text {th }}$ century, symbols for masturbation are not common, but euphemisms are. In 1827 the Dutch writer Jacob van Lennep mentions "sinful moves" in connection to "vulgar thoughts" in his self-diagnostic diary. ${ }^{37}$ Hendrik Jacob Koenen, a Dutch literary scholar, struggled with periods of depression, as we can tell from both his diary and his autobiography. One of the things he worried about was masturbation. At a young age and later as a married man, he felt guilty of "depraved behaviour" and "moral decay." ${ }^{8}$ Koenen was strongly influenced by the orthodox Protestant movement of Le Réveil and felt disturbed by the sermons he heard in church, for example on hidden sins ("sur les petits péchés”). ${ }^{39}$ The Dutch writer Anthony Hartsen was more explicit in his autobiography (1870), which was published without his consent. Hartsen describes his addiction to "zelfbevlekking" (self-pollution) at boardingschool, under the influence of reading Samuel La'Mert's Zelfbewaring ("Self-preservation"). In a published letter he denounced this book as "a stain for the medical profession." 40

Remarkably, in Dutch $19^{\text {th }}$ century literature there are barely any masturbating men, at least not very explicitly. Playing billiards was used as a metaphor for onanism in the Dutch novel Camera Obscura (1839) by Hildebrand (the pseudonym of Nicholas Beets) in which the protagonist Pieter Stastok ("standing cane") is presented as the prototype of the young masturbator: pale, unsociable, drained, scurvy, worried, stingy and wearing glasses. ${ }^{41}$ Female masturbation, however, is adressed more openly. The earliest example in the Netherlands was Lodewijk van Deyssel's Een liefde (1887), a novel which caused a scandal. Van Deyssel was a dandy and leading member of the "Tachtigers" (the progressive literary Movement of the 1880s). In the novel he described in very explicit and purple prose, an orgasm scene involving the female protagonist Mathilda, alone in her garden (Van Deyssel 1974, ch.13). The author himself had to wear an anti-masturbation belt in his youth (Figure 4). In his diary, he records all his bodily workings, including onanism. He even keeps a separate "Onanie-dossier," in which he describes his attempts to control his habit (Prick 2003, 302-305).

Around 1900 the meaning of masturbation changed. Anthropological literature showed that it was only natural: animals (dogs, cats, horses, monkeys, "even elephants"), primitive people and very young children did it. In the works of physicians like Havelock Ellis, Auguste Forel and Richard von Krafft-Ebing, onanism was no longer seen as a disease. The ethical problem of bringing this natural, but uncivilised behaviour into the social, bourgeois order, remained. This is particularly clear in the work of Freud, who thought of masturbation as the result of early, sexual 


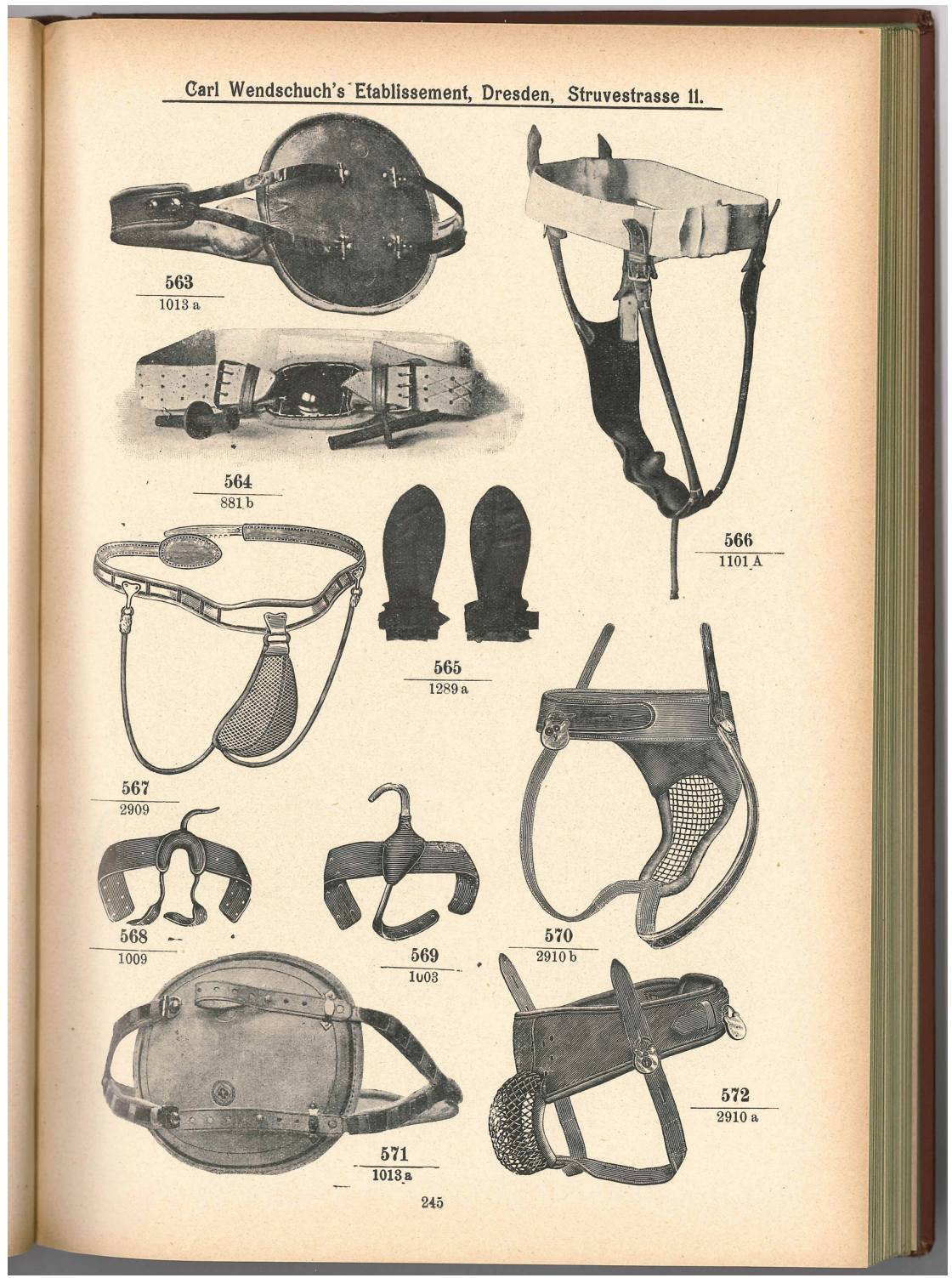

Figure 4 A page from a medical catalogue with anti-masturbation belts for both men and women. (no. 567: "Onaniebandage meiner verbesserten Konstruktion, m. Rückenschloss, männlich", no. 570 and no. 572: "Eine Onaniebandage männliche oder weibliche, für Kinder") and "Onanie-Schutzhandschuhe mit Ledersohlen" (no. 565). Hauptkatalog der Firma Carl Wendschuch (Dresden 1910), 245. 
trauma and the cause of degeneracy, neurosis, hysteria and neurasthenia (Laqueur 2003, 363-396).

Someone who opposed the Freudian as well as the Christian and medical views of masturbation, was the Dutch philosopher Leo Polak (1880-1941) (Figure 5). ${ }^{42}$ His views on sexuality are connected to his engagement with social movements for sexual reform, such as the "Rein Leven Beweging"-a utopian "Pure Life" movement, founded in 1901, that strived for a new sexual morality and advocated greater openness in matters of sexuality. ${ }^{43}$ In his book Sexuele ethiek (1936) he propagated a more relaxed way of dealing with sexuality (albeit within marriage) and a form of eugenetics that would lead to a morally higher human race. ${ }^{44}$ In the last chapter, "Sexual intercourse outside and before marriage," he describes "periodical release through nocturnal ejaculation" as a normal phenomenon of puberty-for boys, not for girls. It is neither a "secret sin" nor "pollution," "pathological," "unhealthy," "abnormal," nor a "symptom of auto-eroticism, narcissism or such erudite nonsens." The devastating illnesses it supposedly would cause are "terrible quackery lies." Ejaculations are necessary and useful to keep both body and mind in shape. In line with his ethical ideas in general, he perceives masturbation not immoral as such, but it depends on the character and moral standards of the one who does it. Humans have the capacity to be more than animals (Polak 1936, 126-128). In specialist circles masturbation became medically benign in the 1930s (Laqueur 2003, 359). Polak's book underpins this rejection of the anti-masturbation discourse of the former centuries.

Polak kept a diary very conscientiously for 40 years (1901-1941). In these diaries, which have become accessible recently, we can see the development of his ethical ideas and his concern for his body; a good character and physical health (he was an enthusiastic swimmer) were closely connected in his view (Wedman 1999, 32; Van der Poel 2016, 146). He did not keep a diary for posterity, but to get a grip on his life and, later in life, to strive for his ideal of "euthemia": ultimate serenity (Van Berkel and Van der Poel 2016, 12). His diaries offer an insight-in all its intimate details - into his ideas on masturbation; not only because he explicitly reflects on the habit itself, but also on the use of symbols to designate it, which makes his diary rather unique. ${ }^{45}$

In his student years the anti-masturbation discourse obviously still had its effect. He considers the possible causes for his "pollutions": his sleeping position, his eating habits, his bowel movement. ${ }^{46} \mathrm{He}$ often regrets doing it:

And still, as I feared, because of no defecation, again polluti[on], again such a sad-tragic spill, destruction of so much supreme life force. ${ }^{47}$ 
The idea that the loss of sperm meant the destruction of life force was already put forward by Tissot and was grounded in humoral theory. At the end of the $19^{\text {th }}$ century physiologists gave a new basis to this theory by applying the laws of energy to human beings. The "spending" of the vital spermatic fluid meant a loss of energy in other areas of life and "moderate" expenditures were most consonant with health and fertility (Oosterhuis 2000, 33). In Polak's view his pollutions exhausted his memory: "I would like to avoid the poll[ution]'s regularly 14 days or for example from now on until my exam; it is much too often for my memory-and

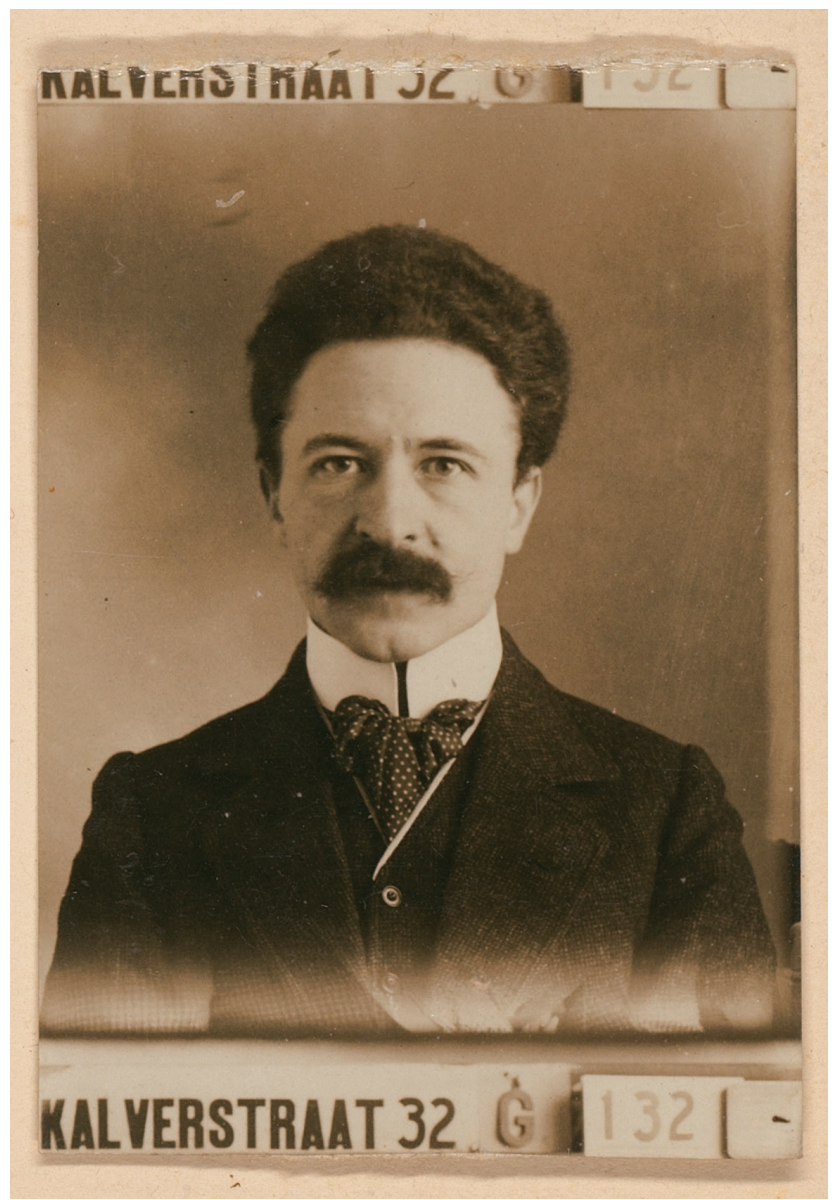

Figure 5 Leo Polak as University teacher in Amsterdam. Special Collections of the University of Amsterdam, Collection Leo Polak, ref. nr. xxx F 14, f. 88. 
everything that depends on it." ${ }^{\text {"8 }}$ His diary was very important for Polak as a memory device. ${ }^{49}$ In a way, his diary-writing healed what was destroyed, in his view, by his masturbation habits.

Polak uses symbols to record and count his ejaculations. On 8 January 1903 he writes the passage I quoted at the beginning of this article:

Mistakenly I have put myself down because of fear for loss of sperm

I counted for 02-03 in total 58.

Our contrary suggestion! $-{ }^{50}$

He takes stock at the beginning of the new year by counting the "loss of sperm" of the past year, 58 instances in total; not as often as he apparently worried about earlier. The use of symbols made it easier to count. Crosses appear regularly, often before the date, sometimes at the end of a day. On 31 March 1903, a date with a cross before it, he questions his usage of symbols explicitly: "Why crosses—instead of pollution?"51 (Figure 6).

Besides the regular crosses ("X"), which appear most frequently, he also uses other symbols: "\#” (number sign), a Christian cross " $\dagger$ " (in various sizes), and a slanting " $\neq$ ". ${ }^{52}$ Polak also kept separate pocket diaries, which are empty, except the "X" and "\#" on several dates (Figures 7 and 8). ${ }^{53}$ Several entries in his diaries suggest that the " $\mathrm{X}$ " indicates ejaculation during sleep, whether or not aroused by erotic dreams-better known today as "wet dreams." He uses the "\#" for masturbation which often leads to ejaculation, although not always on purpose; sometimes he is "surprised" by it. ${ }^{54}$ The other symbols (" $\dagger$ " and " $\ddagger$ ") could indicate a stimulus he sometimes used: a needle. On 15 january 1903 a big " $\nmid$ " appears and the following phrase: "Precisely the only thing that could hurt me, that impedes my happiness, I would bring on to myself? Acu tetigisti. ${ }^{\prime 55}$ Should we take this latin motto at the end to be proverbial ("you have hit the nail on the head") or literal ("you have touched it with a needle")? It seems the latter, when we compare this to later entries in which he more or less explicitly writes about sticking a needle in his penis. ${ }^{56}$

The meaning of the symbols changes over the years: denoting (solitary) ejaculation in his younger years and later in life, when he got married, it indicated sexual intercourse. In his student years his sexual activity is mostly concerned with desire; his longing for female beauty and his dreams about this. He is afraid that his "imaginations of girls in the evenings and mornings" are spoiled by his erections: "thus hesitating, to spoil your safe Beauty with an erection." ${ }^{57}$ These desires often appear in connection with a cross, for example when he dreams about a "suddenly passing "girl with 3 breasts" cause of a poll. [ution], to my annoyance. ${ }^{58} \mathrm{He}$ discusses his ejaculations with his mother, who also reads his diary, although not everything: some parts on his intimate desires he wants to keep to himself. ${ }^{59}$ 


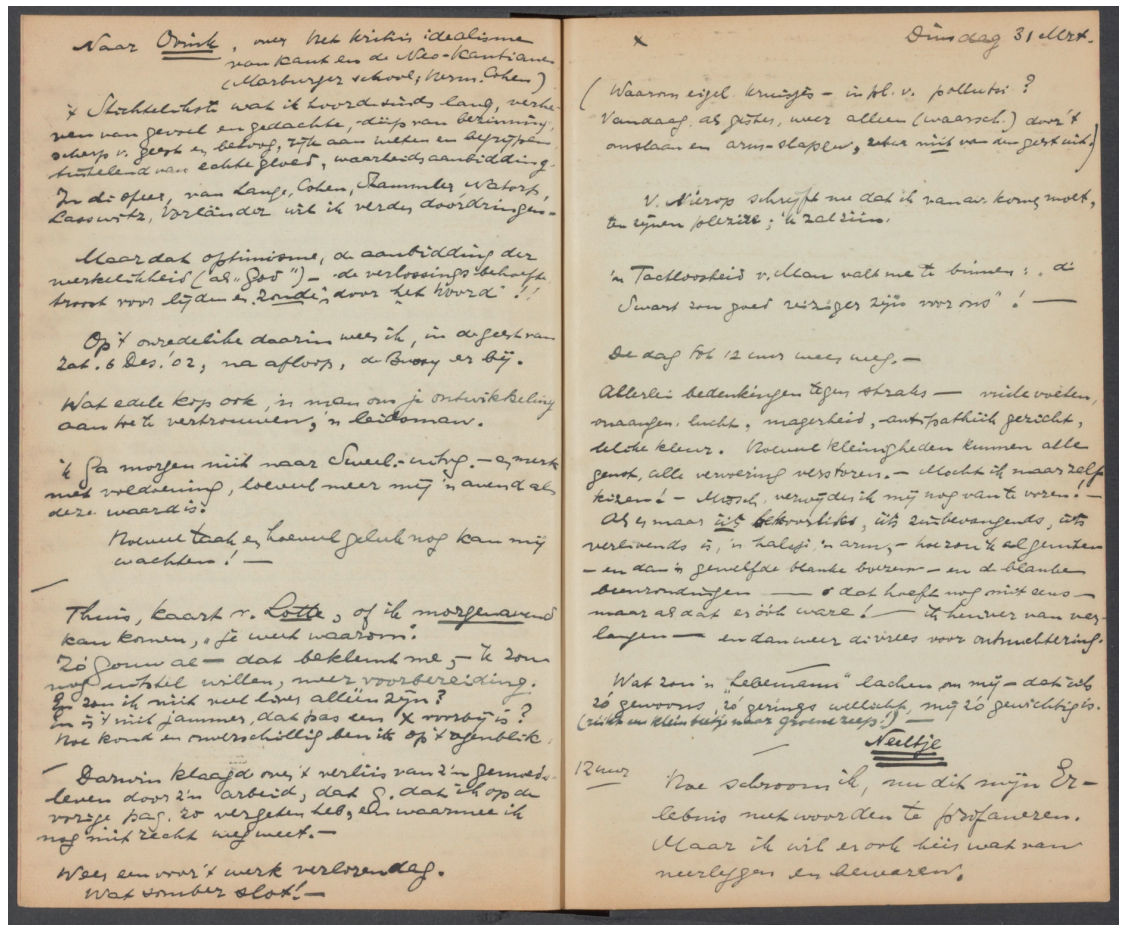

Figure 6 Two pages from the diary of Leo Polak with above on the right the entry with a cross: "Why crosses - instead of pollution?" Special Collections of the University of Amsterdam, Collection Leo Polak, Diary Leo Polak, ref. nr. xxx F 3, f. 87.

On 16 July 1917 he married Henriette ("Jet") Antoinette Schwarz (Langemeier 2013). There are no entries on the wedding and bridal days in his diary. After two empty pages (which he possibly later wanted to use for an entry on his marriage) the first entry is on 17 August and starts with a cross. Sometimes several crosses appear at one date ("XX Vrijdag 24 Aug"). The connotation changes to denote sexual intercourse with his wife. A month after his marriage, he writes:

X thursd. 21 Again a lovely, sweet, elegant late summerday; with too little work. A mosquito slightly awakened me early in the night, ergo poll., and fear of pregnancy. It would be a nice chain of causation $!^{60}$

Polak and his wife had to wait a little longer to become pregnant. On 1 July 1918 a cross appears with an exclamation mark behind the date. 

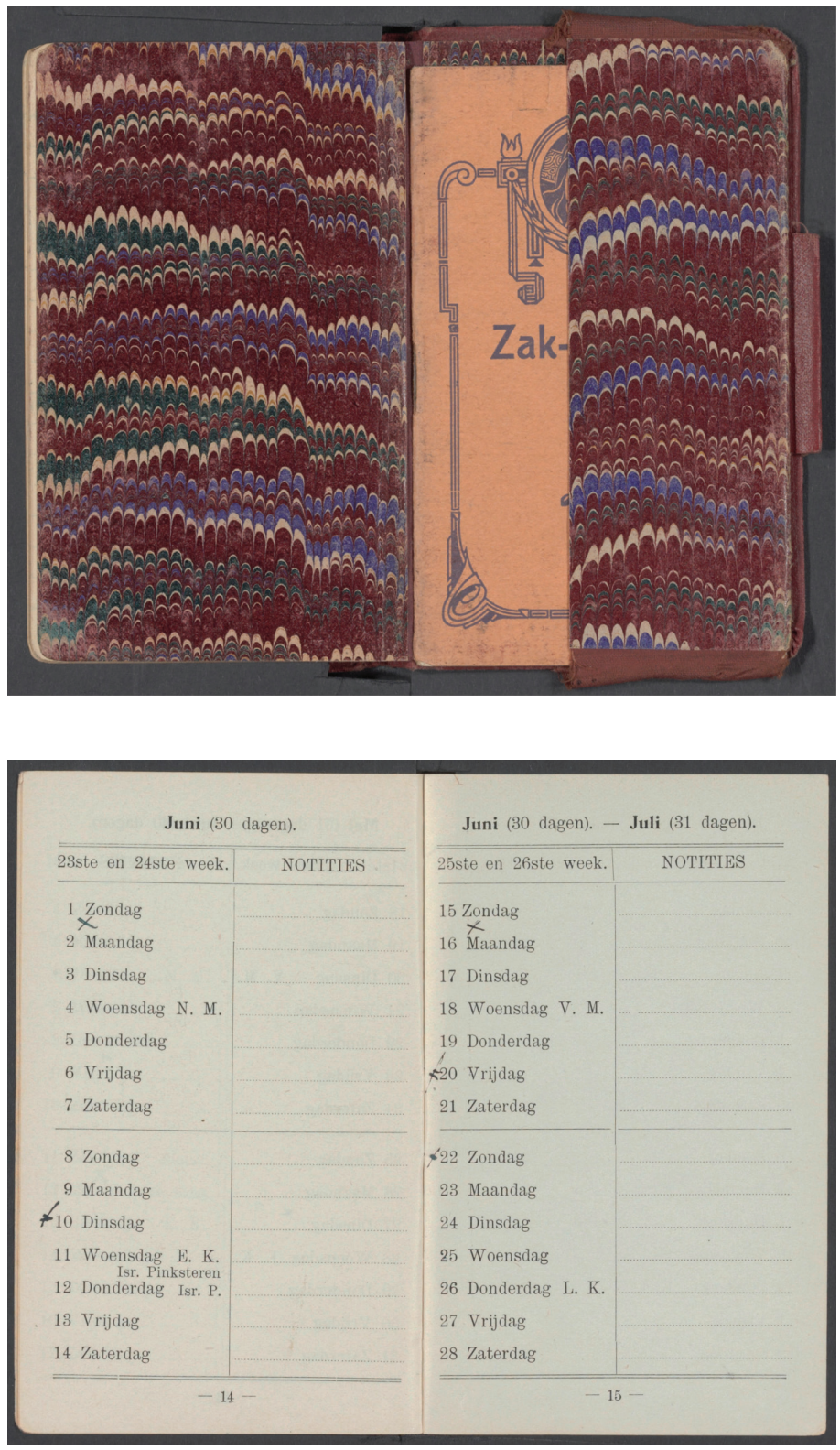

Figures 7 and 8 The pocket diary of 1913 in which Polak recorded "X" and "\#”. Special Collections of the University of Amsterdam, Collection Leo Polak, Diary Leo Polak, ref. nr. $x x x$ F 15, f.84 and f.94. 
On 31 July he writes: "Everything well! (messages in Zandv.[oort] en to Sleeswijk, happily expecting)." ${ }^{11}$ On 23 March 1919, nine months after the cross with the exclamation mark, their first daughter Bettina was born.

Also in his later years, the crosses appear regularly. On 12 January 1941, during World War II, he wrote: "In train to Amst.[erdam], nicely heated 2e cl. compartment for just the two of us-immediately ceased the opportunity as young couple $\mathrm{X} .{ }^{\prime 62}$ This was the last cross in his diary. A month later, Polak was arrested, because he resisted the anti-Jewish measures at the university. In the early days of his imprisonment he stayed optimistic and imperturbable in his aim for "euthymia." He tried to keep in good physical shape but later on, he lost hope. On 6 May 1941 his diary ends with a memory from his youth. Polak was transported to the Nazi concentration camp, Sachsenhausen, where he died from exhaustion on 9 December 1941 (Van der Poel 2016, 156-168).

\section{CONCLUSIONS}

Tiny symbols in diaries can tell big stories. By simultaneously naming and concealing, these symbols reveal certain crucial aspects of diary writing in its discursive context. In this article I have concentrated on symbols with regard to the discourse on masturbation. I have analysed these symbols not as "silence," but as disguising, narrative strategies. They form an integral part of the text-therefore this article is also a plea to editors to incorporate them in published editions of diaries, which, unfortunately, hitherto has not always been the case.

The central question was how authors, by employing disguising strategies (such as symbols) in diaries, position themselves within and against public discourses on masturbation. The choice of masturbation as a case study for disguising strategies was not coincidental. It allows the complex relationship between discourse and experience to be scrutinised. A symbol or code is private language, that is embedded in a discursive context. The anti-masturbation discourse was visible in the crosses and stars which were used by diarists such as Huber and Van Goltstein to control their "secret vice." In that sense, disciplining and controlling the body using a daily (or nocturnal) activity of diarywriting is in line with the broader development of "controlling time" in diaries (Baggerman 2011). Personal experiences in diaries are shaped by this discursive context. But what about the agency and subjectivity of the diarists themselves?

The dominance of the anti-masturbation discourse is not the whole story. Self-narratives not only react to discourse, but they-or their authors-can also act (Porter 2004; Ruberg 2010; Stolberg 2011). What opportunities did the diarists take to change or resist certain discourses? 
Regardless of Huber's Ach and Weh's and despite Van Goltstein's list of bad traits, both adolescents persisted in their habits nonetheless. Lister condemns onanism in public, but does it in private and Polak uses his diary to reassure himself that his "fear for loss of sperm" was mistaken. Later in life he resists the "quackery" about masturbation altogether.

Diaries are performative, they can do something to the author and the reader (Ruberg 2010). As a memory device, they help to remember the bigger and smaller events in life-for oneself, but also for (potential) readers. A diary can function as a medium to register and control physical processes, such as sleep, nutrition, excretion, movement and sexuality. In our digital age, apps and social media tools to monitor the body have taken over this function of the diary (Lupton 2013). Symbols in diaries were a short and practical way to count and keep track of a repetitive activity like masturbation. In that way, it reminds us of the origins of the diary as an offshoot of the account book; a dated record of commercial transactions (Lejeune 2009, 51). The privacy of a diary encourages the confiding, in a dialogue with him- or herself, of things of which the author does not speak (Stevenson 2000, 224). But the symbols for masturbation show that this privacy is relative. Symbols also disguise the habit which indicates that a reader is simultaneously presupposed and contrived. Like a note which says "burn before reading," or the request "don't think of a pink elephant," encryptions attract attention. By concealing, they reveal; by disguising, they disclose.

Anne Lister's diary, a landmark for lesbian history as an (encoded) account of love and sex between women, shares the use of a symbol for masturbation, accompanied by negative opinions about onanism, with some male diarists of the same age. The fact that there are hardly any daries by (young) women in which masturbation, or sexuality in general, is mentioned, cannot be explained by the presumption that the anti-masturbation discourse was not aimed at girls and women (for it was) or that they did not masturbate (they probably did). With few exceptions, the diaries of young girls and women were self-censored-for sexual matters in general, and for masturbation in particular-presumably, because of the dangers that were perceived as even worse for women, since it contradicted their proper, societal role as (future) mothers and wifes. The self-censoring consequences of societal pressures, and the ignorance of sexual matters, became clear in the diary of Caroline van Loon.

The words and symbols for masturbation in diaries could differ ("fatal," Pisces-symbol, crosses, stars, number sign), but there were also similarities between diarists of different nationalities, which indicate that diarists were influenced by famous authors, in graphically encoding masturbation. Another similarity is the fact that the symbols often appear 
between two dates, to indicate that it usually is a nocturnal activity-in this sense the meaning of the word "diary," from the Latin diarium, "daily allowance," from dies "day" - tells only half the story.

Polak was the most sophisticated in his use of a variety of symbols (most importantly the "X" and the "\#"), which allowed him to distinguish between ejaculation during sleep and masturbation. The connotation of the " $\mathrm{X}$ " changed as well over time; from "pollution" to sexual intercourse with his wife. His diary is exceptional, because he reflected on the habit of masturbation itself and on the use of symbols to denote it. Although the anti-masturbation discourse gradually faded out in the $20^{\text {th }}$ century, in Polak's early diary the urge to control physical and sexual activity is still visible. In his worries and precautions, the anti-masturbation discourse still resonates but in his later published work he opposes these ideas-in line with the development of the medical discourse in the 1930s-and takes a more relaxed stand on masturbation.

In the sexual revolution of the 1960s and 1970s masturbation became one of the key issues in the proclamation of individual liberty and the autonomy of the body (Laqueur 2003, 361). Whether it appears more frequently in diaries (or their modern digital equivalents) denoted by symbols or otherwise, or rather disappears because it is no longer seen as malignant, is a question that lies outside the scope of this article. Today, generally speaking, masturbation is no longer seen as a problem, that is if you somehow keep it private and discreet. However, any discussion on the subject, even in scholarly contexts, still causes embarrassment to some degree (Mason 2008, 2). Some people think it should be discussed more openly and want to make this private matter public again, inferred from initiatives like "National Masturbation Month" and masturbation networks, both real and virtual (Laqueur 2003, 361-362). Recently, a Dutch design student invented a "masturbation suit": "a suit in which women can indulge themselves always and everywhere" in order "to relieve the taboo and to make the topic more open for discussion" (Meijer 2017).$^{63}$ The antimasturbation belt of the $19^{\text {th }}$ century has changed into a "masturbation suit"; the past is a foreign country, but also has some familiar features.

My aim with the study of symbols for masturbation in diaries, was to stress the importance of this kind of "private language," for it can tell bigger stories: about diaries as a genre, about the relation between discourse and experience, about the cultural history of medicine and the history of the body and sexuality. But besides this case study, there are several other disguising strategies both inside and outside the text, which deserve more attention: abbreviations, mirror writing, foreign language, anagrams, crossed out lines, empty pages, deleted parts, locks on diaries, etc. These "silences" form an integral part of storytelling and deserve to be studied as such. 


\section{BIBLIOGRAPHY}

\section{Primary sources}

\section{Archival sources}

Autobiography H.J. Koenen, Special Collections of the University of Amsterdam, ref. nr. RA A13.

Diary Alexander von Goltstein, Gelders Archief, Family archive Van Goltstein (0568), ref. nr. 64 a.

Diary Anne Lister, West Yorkshire Archive Service, Calderdale, ref. nrs. SH: 7/ML/E/1-26 and RAM: 52-76, 78-79.

Diary Caroline van Loon, Special Collections of the University of Amsterdam, ref. nr. RA.01: 0018-0023.

Diary Leo Polak, Special Collections of the University of Amsterdam, ref. nr. xxx F 3.

Diary Robert Hooke, kept from 10 March 1671/2 to 16 May 1683, Collection Robert Hooke, London Metropolitan Archives, ref. nr. MS 01758, 1666-1683.

\section{Printed sources}

Goltstein, Alexander van. De vertrouwde van mijn hart: Het dagboek van Alexander van Goltstein (1801-1808). Ed. Jurgen Limonard. Hilversum: Verloren, 1994.

Lister, Anne. The Secret Diaries of Miss Anne Lister (1791-1840). Ed. Helena Whitbread. London: Virago, 2010.

Hartsen, F. A. Nederlandsche toestanden. Uit het leven van een lijder. Ed. Nop Maas. Hilversum: Verloren, 1996.

Deyssel, Lodewijk van. Een liefde. Den Haag: Uitgeverij Bert Bakker, 1974.

Polak, Leo. Sexuele ethiek. Amsterdam: N.V. Uitgevers-Maatschappij Kosmos, 1936.

Pepys, Samuel. The Diary of Samuel Pepys. Vol. I-XI. Eds. Robert Latham and William Matthews. London: Bell \& Hyman, 1983.

Onania (reprinted at Boston, 1724), Evans Early American Imprint Collection, http://name. umdl.umich.edu/N02163.0001.001, accessed 30 January 2017.

\section{Secondary sources}

Baggerman, Arianne and Rudolf Dekker. Child of the Enlightenment: Revolutionary Europe Reflected in a Boyhood Diary. Leiden: Brill, 2009.

Baggerman, Arianne. "Lost Time: Temporal Discipline and Historical Awareness in Nineteenth-Century Dutch Egodocuments." Ed. Michael Mascuch, Rudolf Dekker, and Arianne Baggerman. Controlling Time and Shaping the Self : Developments in Autobiographical Writing Since the Sixteenth Century. Leiden: Brill, 2011. 455-541.

Berkel, Klaas van and Stefan van der Poel. "Leo Polak, filosoof van het vrije denken. Een inleiding." Ed. Raphael Idem. Nieuw licht op Leo Polak (1880-1941): Filosoof van het vrije denken. Hilversum: Verloren, 2016. 9-14.

Bloom, Lynn Z. "I Write for Myself and Strangers: private diaries as public documents.” Eds. Suzanne L., Bunkers and Cynthia Anne Huff, Inscribing the Daily: Critical Essays on Women's Diaries. Amherst: University of Massachusetts Press, 1996. 23-37.

Brodie, Janet Farrell. "Menstrual Interventions in the Nineteenth Century United States." Eds. Etienne van de Walle and Elisha P. Renne. Regulating Menstruation: Beliefs, Practices, Interpretations. Chicago: University of Chicago Press, 2001. 39-63. 
Burke, Peter. "Historicizing the Self, 1770-1830." Eds. Michael Mascuch, Rudolf Dekker and Arianne Baggerman. Controlling Time and Shaping the Self: Developments in Autobiographical Writing Since the Sixteenth Century. Leiden: Brill, 2011. 13-32.

Carroll, Brian D. "II Indulged My Desire Too Freely': Sexuality, Spirituality, and the Sin of Self-Pollution in the Diary of Joseph Moody, 1720-1724." The William and Mary Quarterly 60.1 (2003): 155-170.

CLARIN Virtual Language Observatory, https://vlo.clarin.eu/search?4\&fq=collection:Mee rtens+Collections+-+NDA, accessed 9 January 2017.

Dekker, Rudolf. Childhood, Memory and Autobiography in Holland: From the Golden Age to Romanticism. Basingstoke, etc.: Macmillan, 2000.

Delafield, Catherine. Women's Diaries as Narrative in the Nineteenth-Century. Surrey: Ashgate, 2009.

Downing, Lisa and Diane Mason. "The Secret Vice: Masturbation in Victorian Fiction and Medical Culture." Social History of Medicine 22.3 (2009): 639-640.

"Egodocumenten 1814-1914 (repertorium)," Onderzoeksinstituut Egodocument en Geschiedenis, http://www.egodocument.net/egodocumententot1814.html, accessed 9 January 2017.

"Egodocumenten 1814-1914." Onderzoeksinstituut Egodocument en Geschiedenis, http:// www.egodocument.net/egodocumententot1814.html, accessed 9 January 2017.

"Egodocumenten tot 1814." Onderzoeksinstituut Egodocument en Geschiedenis, http:// www.egodocument.net/egodocumententot1814.html, accessed 8 January 2017.

Etter, Paul. "Johann Caspar Lavaters Geheimschriften im 'Geheimen Tagebuch'." Zürcher Taschenbuch 74 (1954): 67-73.

Foucault, Michel. Abnormal: Lectures at the Collège De France, 1974-1975. 1st Picador USA ed. New York: Picador, 2003.

Foucault, Michel. The History of Sexuality: An Introduction. Ed. Trans. R. Hurley. New York: Vintage Books, 1990.

Garlick, Steve. "The Biopolitics of Masturbation: Masculinity, Complexity, and Security." Body E Society 20.2 (2014): 44-67.

Gay, Peter. Education of the Senses. The Bourgeois Experience: Victoria to Freud, vol. 1. New York: Oxford University Press, 1984.

Gay, Peter. The Naked Heart. The Bourgeois Experience: Victoria to Freud, vol. 4. New York, N.Y.: Norton, 1995.

Grantham Turner, James. Schooling Sex: Libertine Literature and Erotic Education in Italy, France, and England 1534-1685. New York: Oxford University Press, 2003.

Hallgrimsdottir, Gudny. "Material without Value?: The Recollections of Guðrún Ketilsdóttir." Eds. Anna Kuismin and M. J. Driscoll. White Field, Black Seeds: Nordic Literacy Practices in the Long Nineteenth Century. Helsinki: Finnish Literature Society, 2013. 134-145.

Hekma, Gert. "De belaagde onschuld. Een strijd tegen zelfbevlekking in Nederland?" Eds. Gert Hekma and Herman Roodenburg. Soete Minne En Helsche Boosheit: Seksuele Voorstellingen in Nederland, 1300-1850. Nijmegen: SUN, 1988. 234-237.

Hocke, Gustav René. Europäische Tagebücher Aus Vier Jahrhunderten: Motive Und Anthologie. Frankfurt am Main: Fischer Taschenbuch Verlag, 1991.

Holmes, Katie. "Marking Time: Australian Women's Diaries of the 1920s and 1930s." Eds. Michael Mascuch, Rudolf Dekker and Arianne Baggerman. Controlling Time and Shaping the Self: Developments in Autobiographical Writing Since the Sixteenth Century. Leiden: Brill, 2011. 169-196.

Huisman, Marijke. Publieke Levens: Autobiografiën op de Nederlandse boekenmarkt 1850-1918. Zutphen: Walburg Pers, 2008.

Kemperink, Mary. Het verloren paradijs. De Nederlandse literatuur en cultuur van het fin de siècle. Amsterdam: Amsterdam University Press, 2001. 
Kurvet-Käosaar, Leena. Embodied Subjectivity in the Diaries of Virginia Woolf, Aino Kallas and Anaïs Nin. Tartu: Tartu University Press, 2006.

Langemeijer, G.E. "Polak, Leonard (1880-1941)." Biografisch Woordenboek van Nederland. URL: http://resources.huygens.knaw.nl/bwn1880-2000/lemmata/bwn2/polak [12-112013], accessed 30 january 2017.

Laplanche, Jean. The Language of Psycho-analysis. London: Karnac Books, 1988.

Laqueur, Thomas W. Solitary Sex: A Cultural History of Masturbation. New York, N.Y.: Zone Books, 2003.

Lejeune, Philippe. On Diary. Honolulu: University of Hawai’i Press, 2009.

Liddington, Jill. Presenting the Past: Anne Lister of Halifax, 1791-1840. Hebden Bridge, West Yorkshire: Pennine Pens, 1994.

Lindeman, Ruud, Yvonne Scherf, Arianne Baggerman and Rudolf Dekker, eds. Egodocumenten van Nederlanders uit de zestiende tot begin negentiende eeuw: Repertorium. Amsterdam: Panchaud, 2016.

Lister, Anne and Jill Liddington. Female Fortune: Land, Gender and Authority: The Anne Lister Diaries and Other Writings, 1833-36. London: Rivers Oram, 1998.

Longsworth, Polly, Austin Dickinson and Mabel Loomis Todd. Austin and Mabel: The Amherst Affair $\mathcal{E}$ Love Letters of Austin Dickinson and Mabel Loomis Todd. New York: Farrar, Straus, Giroux, 1984.

Lupton, Deborah. "Quantifying the Body: Monitoring and Measuring Health in the Age of mHealth Technologies.” Critical Public Health 23.4 (2013): 393-403. http://dx.doi.org/10. 1080/09581596.2013.794931

Magnússon, Sigurður Gylfi. "Gender: A Useful Category in the Analysis of Ego-Documents?” Scandinavian Journal of History 38.2 (2013): 202-222.

Mathijsen, Marita. De gemaskerde eeuw, Amsterdam: Querido, 2003.

Mathijsen, Marita. "Zondige bewegingen." https://maritamathijsen.wordpress. com/2016/01/29/zondige-bewegingen, published 29 January 2017, accessed 30 January 2017.

Mascuch, Michael, Rudolf Dekker and Arianne Baggerman. "Egodocuments and History: A Short Account of the Longue Durée." Historian 78.1 (2016): 11-56.

Mason, Diane Elizabeth. The Secret Vice: Masturbation in Victorian Fiction and Medical Culture. Manchester: Manchester University Press, 2008.

Meijer, Eveline. "Masturbatiepak moet zelfbevrediging bespreekbaar maken." Algemeen Dagblad, 26 October 2016, http://www.ad.nl/lifestyle/masturbatiepak-moet-zelfbevrediging-bespreekbaar-maken a9c6c718/, accessed 30 January 2017.

"Metadata van dagboeken," http://www.meertens.knaw.nl/cms/nl/nieuws-agenda/nieuws-overzicht/231-2016/145151-metadata-van-dagboeken, accessed 9 January 2017.

Millim, Marie. "The Victorian Diary: Between the Public and the Private." Literature Compass 7.10 (2010): 977-988. http://onlinelibrary.wiley.com/doi/10.1111/j.17414113.2010.00750.x/epdf.

Mulligan, Lotte. "Self-Scrutiny and the Study of Nature: Robert Hooke's Diary as Natural History." Journal of British Studies 35.3 (1996): 311-342.

Oosterhuis, Harry. Stepchildren of Nature. Krafft-Ebing, Psychiatry, and the Making of Sexual Identity. Chicago, IL: University of Chicago Press, 2000.

Orr, Dannielle. A Sojourn in Paris 1824-1825. Sex and Sociability in the Manuscript Writings of Anne Lister (1791-1840), Bachelor thesis, Murdoch University, 2006. http://researchrepository.murdoch.edu.au/id/eprint/235/, accessed 29 May 2017.

Piller, Gudrun. Spuren Des Leibes in Selbstzeugnissen Des 18. Jahrhunderts. Köln etc.: Böhlau, 2007.

Piller, Gudrun. "Private Body-What Do Self-Narratives Bring to the History of the Body?" Eds. Claudia Ulbrich, Kaspar von Greyerz and Lorenz Heiligensetzer. Map- 
ping the 'I'. Research on Self-Narratives in Germany and Switzerland. Leiden/Boston: Brill, 2015. 76-94.

Poel, Stefan van der. “'Euthemia bleibt uns'. De laatste jaren van Leo Polak, 1938-1941.” Eds. Klaas van Berkel and Stefan van der Poel. Nieuw licht op Leo Polak (1880-1941): Filosoof van het vrije denken. Hilversum: Verloren, 2016. 139-168.

Poldervaart, Saskia. "Utopianism and Sexual Politics in Dutch Social Movements." http:// www.iisg.nl/womhist/poldervaart-2003.doc, accessed 30 January 2017.

Porter, Porter. "History of the Body." Ed. Peter Burke. New Perspectives on Historical Writing. Oxford: Oxford University Press, 1991. 206-232.

Porter, Roy. "More than a Foreword." Eds. Willem de Blécourt and Cornelie Usborne. Cultural Approaches to the History of Medicine: Mediating Medicine in Early Modern and Modern Europe. New York: Palgrave Macmillan, 2004, x-xvii.

Prick, Harry G.M. Een vreemdeling op de wegen. Het leven van Lodewijk van Deyssel vanaf 1890, Amsterdam: Athenaeum-Polak \& Van Gennep, 2003.

Revealing Anne Lister, directed by Matthew Hill (BBC, 2010).

Rosario, V.A. "Thomas W. Laqueur. Solitary Sex: A Cultural History of Masturbation." Bulletin of the History of Medicine 78.4 (2004): 908-909.

Rowanchild, Anira. "'Everything Done for Effect': Georgic, Gothic and Picturesque in Anne Lister's Self-Production.” Women's Writing 7.1 (2000): 89-104.

Rowanchild, Anira. "'My Mind on Paper'. Anne Lister and the Construction of Lesbian Identity." Eds. Alison Donnell and Pauline Polkey. Representing Lives. Women Auto/Biography. Basingstoke etc.: Macmillan, 2000. 199-207.

Ruberg, Willemijn. "The Letter as Medicine: Studying Health and Illness in Dutch Daily Correspondence, 1770-1850." Social History of Medicine 23.3 (2010): 492-508.

Schmeh, Klaus. "Encrypted Books: Mysteries that Fill Hundreds of Pages." Cryptologia 39.4: 342-361, DOI: 10.1080/01611194.2014.988369, published online 17 june 2015.

Schneider, Manfred. "Chiffrierte Sekrete," KulturRevolution, 24 (1991): 59-63.

Schoor, Rob van de. "Onanie". Eds. Anne van Buul et al. Onnoemelijke dingen: Over taboe en verbod in het fin de siècle. Hilversum: Verloren, 2014. 202-203.

Sontag, Susan. "The Aesthetics of Silence." Ed. Raphael Idem. Styles of Radical Will. New York, N.Y.: Dell Publishing Co., 1969. 3-34.

Stevenson, David. "Recording the Unspeakable: Masturbation in the Diary of William Drummond, 1657-1659." Journal of the History of Sexuality 9.3 (2000): 223-239.

Stolberg, Michael. "Self-Pollution, Moral Reform, and the Venereal Trade: Notes on the Sources and Historical Context of Onania (1716)." Journal of the History of Sexuality 9.1/2 (2000): 37-61. http://www.jstor.org/stable/3704631.

Stolberg, Michael. "The Crime of Onan and the Laws of Nature. Religious and Medical Discourses on Masturbation in the Late Seventeenth and Early Eighteenth Centuries." Paedagogica Historica 39.6 (2003): 701-717. http://dx.doi.org/10.1080/0030923032000128863.

Stolberg, Michael. Experiencing Illness and the Sick Body in Early Modern Europe. Basingstoke etc.: Palgrave Macmillan, 2011.

Toulalan, Sarah and Kate Fisher. The Routledge History of Sex and the Body: 1500 to the Present. Abingdon, Oxon: Routledge, 2013.

Vermeer, Leonieke. "Papa is weder ongesteld': Ziektebeleving in negentiende-eeuwse egodocumenten." De Negentiende Eeuw 39.3/4 (2015): 230-251.

Vermeer, Leonieke. "'Waarom eigenlijk kruisjes in plaats van pollutie?' Het dagboek (19011941) van Leo Polak in relatie tot het discours tegen masturbatie." De Moderne Tijd. De Lage Landen, 1780-1940 1.2 (2017): 134-159.

Wedman, Homme. "Op zoek naar Euthymia. Leo Polak 1880-1941." Geschiedenis van de Wijsbegeerte in Nederland 10.2 (1999): 16-32.

Whitbread, Helena and Natasha Holme. Secret Diaries: Past E Present: QEंA, 2016. 


\section{ABOUT THE AUTHOR}

Leonieke Vermeer is Assistant Professor of Modern History at the University of Groningen. http://www.rug.nl/staff/l.k.vermeer/.

\section{NOTES}

1 "Ten onrechte heb ik mij down laten maken door vrees van te veel sperma-verlies. ' $\mathrm{k}$ Telde van 02-03 in 't geh[heel] 58. Ons tegengestelde suggesti[e] tans!" Diary Leo Polak, Special Collections of the University of Amsterdam, hs. xxx F 3, part 3, 8 January 1903.

2 On Leo Polak, see: Van Berkel and Van der Poel 2016.

3 Mascuch/Dekker/Baggerman 2016, 49. The authors argue that there has not been any research done on this topic, but this is not entirely the case, as will be shown in the next paragraph.

4 A short definition of discourse is: "Discourses establish what can be said on a given topic at a specific point in time because it is important and because it is 'true'. They also determine what a person can say at all by communicating the standards of what is relevant and what is correct. Thus they create a certain context for discussions within society, but they remain mutable." (Martin Dinges cited by Piller 2015, 79).

5 For this method of alternation between model sources and additional texts see: Piller 2015, 92-93.

6 " [...] aus den Erfahrungen von Unfreiheit innerhalb des Privaten wie des Öffentlichen.” Hocke 1991, 164.

7 For a critical assessment of the exclusive approach to diaries by New Criticism (and feminist critics) see: Millim 2010, 977-980.

8 "In Tagebüchern die 'alles sagen', wird das 'letzte' Intime oft auf mehr oder weniger erfindungsreiche Art verborgen.” Hocke 1991, 162.

9 "Egodocumenten 18141914 (repertorium)." Onderzoeksinstituut Egodocument en Geschiedenis, http://www.egodocument.net/egodocumententot1814.html. Accessed 9 January 2017.

10 For example: the diary of Caroline van Loon with comments by her fiancé in the margins, which I will mention later in this article.

11 See for a critical assessment of these notions: Kurvet-Käosaar 2006, 40-71, 69-70.

12 The collection contains approximately 2000 ego-documents of which 1000 diaries have been registered. "Metadata van dagboeken," http://www.meertens.knaw.nl/cms/nl/ nieuws-agenda/nieuws-overzicht/231-2016/145151-metadata-van-dagboeken, accessed 9 January 2017. These metadata are searchable via: CLARIN Virtual Language Observatory, https://vlo.clarin.eu/search? $4 \&$ fq =collection:Meertens+Collections+-+NDA

13 "Egodocumenten tot 1814." Onderzoeksinstituut Egodocument en Geschiedenis, http://www.egodocument.net/egodocumententot1814.html, accessed 8 January 2017; Lindeman $(2016,22)$ argues that this percentage is representative for the common pattern in Western Europe.

14 The complete title is: Onania: or, the heinous sin of self-pollution and all its frightful consequences (in both sexes) considered with spiritual and physical advice to those who have already injured themselves by this abominable practise. There are no known copies of the first three editions. Tissot attributes the pamphlet to an individual named Bekker. It has been maintained that this is the Dutch theologian Dr. Balthazar Bekker. But Michael Stolberg has convincingly argued that the author of the pamphlet was John Marten, a (self-proclaimed) 
specialist in venereal diseases who had very concrete financial and commercial interests in this issue. (Stolberg 2000, 50; Stolberg 2003, 710-711).

15 Tissot's book first appeared in Latin in 1758 and was favorably greeted by specialists, but received almost no attention. The circulation of the first French edition (1760) was restricted to medical circles. Foucault 2003, 259, n.3.

16 Kramers Algemeene Kunstwoordentolk (1847). Search via: De Geïntegreerde Taalbank, http://gtb.inl.nl/, accessed 12 January 2017.

17 Search via: Delpher, http://www.delpher.nl/. Newspaper articles in the $19^{\text {th }}$ century: 'onanie' (1564 hits), 'zelfbevlekking' (1201 hits), 'masturbatie' (55 hits).

18 Genesis 38:8-10. On the different religious interpretations of this Biblical story, see: Stevenson 2000, 225.

19 Downing 2009, 640. The term 'autoeroticism' was popularised toward the end of the $19^{\text {th }}$ century by British sexologist Havelock Ellis. Laplanche 1988, 45.

20 See for an overview: Rosario 2004; Hekma, 232.

21 Foucault 1990, 103-104. Foucault's original intention was to devote a volume of his History of sexuality to this topic, but this never came to fruition. Instead, his only sustained attention to masturbation is found in one of his lectures at the College de France in 1975: Foucault 2003, 231-262; Garlick 2014, 45.

22 The diaries of Samuel Pepys and James Boswell are mentioned in Laqueur 2003, 40, 180-182. On masturbation in Pepys's diary, see also: Grantham Turner 2003, 223-240. Furthermore: Piller 2015; Schneider 1991; Carroll 2003; Stevenson 2000.

23 See for several publications: Grantham Turner 2003, 3-4.

24 Laqueur 2003, 180-182. The index to the Latham and Matthews edition, vol. 11, gives all the instances (14 entries) in which Pepys mentions masturbating (Pepys 1983, vol. 11 Index, 261).

25 I thank dr. Rina Knoeff for drawing my attention to Robert Hooke's journal.

26 Diary kept from 10 March 1671/2 to 16 May 1683, Collection Robert Hooke, London Metropolitan Archives, ref. nr. code CLC/495/MS01758 (available as online resource). Most of the diary was published in 1935 as The Diary of Robert Hooke 1672-1680, M.A. F.R.S. 1672-1680 (Taylor \& Francis, London 1935), edited by Henry W. Robinson and Walter Adams. However, Robinson and Adams chose not to publish entries from March to July 1672 and from January 1681 to May 1683. This material has been published as "Unpublished material from the memorandum book of Robert Hooke, Guildhall Library Ms 1758" by Henderson 2007.

27 The first known diary of a child is that of Otto van Eck: Baggerman and Dekker 2009.

28 "Heute stuhnd ich erst vor 8 Uhr auf --+ n.g.m.fl. $----!-!--<\mathrm{xxx}>$ —." Huber, Tagebuch meiner selbs (t), 24(1), as cited by Piller 2015, 87.

29 "Musste mich ein wenig einkleiden, damit ich die mama über Rhein begleiten könne. u. da wars als wied. geschah. ++! abscheulich!! - - ". Huber, Tagebuch meiner selbs(t), 55 (1), as cited by Piller 2015, 88.

30 "Ach dann + !!!! — — Bald ein 1/2 Jahr — weh! weh! Machte meine Laken." Huber, Tagebuch meiner selbs (t), 36 (2), as cited by Piller 2015, 91.

31 Entries in Van Goltstein's diary: 30 September 1802; 24 July 1805; 15 October 1805; 28 August 1806. Van Goltstein 1994, 61, 79, 83-84, 101. On the preventive measures in the anti-masturbation literature, see: Hekma 1988, 239-240.

32 'want alle posterijen en je journalen van zoo te verlangen te trouwen en met de beplakte passage van je kokende liefde voor mij.' The manuscript of the diary does not contain these stuck on pages anymore, but it could also have referred to stuck on pages in the letters ('alle posterijen'). Diary of Caroline van Loon, inv.nr: 0019, pp. 136-142. I thank Maria van der Drift for her research on the manuscript of Caroline van Loon, carried out during the Open University Summer School 'Lijdende levens. Ziektebeleving in 
negentiende-eeuwse egodocumenten', 10-14 June 2013, in cooperation with the Special Collections of the University of Amsterdam.

33 The story of the concealment, recovery, decoding and reception of the diaries is a story in itself. See the introduction of Helena Whitbread in Lister 2010, xiii-xxv; Liddington 1994; Rowanchild 2000.

34 Lister 2010, xiii. This edition by Helena Whitbread contains only selections from the diary from the years 1816-1824. The original version of the diaries is held by the Calderdale District Archives, ref. nrs. SH: 7/ML/E/1-26 and RAM: 52-76, 78-79.

35 Lister 2010, 110, 402. See for other euphemisms in her diary: http://rictornorton.co.uk/ lister.htm, accessed 30 January 2017.

36 I thank Helena Whitbread for her helpful comments on this passage on Anne Lister's diaries.

37 "O Heer! dood toch in mij die wortel van kwade bewegingen door de algenoegzame kracht uws geestes!"; "O Heer! reinig mijn harte en zuiver mij van onkuische gedachten en bewegingen."; "Verscheidene zondige bewegingen gevoeld en den wil niet gehad om die te onderdrukken. O God! wat ben ik een zondig mensch! wie zal mij verlossen van dit lichaam des doods?" Diary Jacob van Lennep, August 22-September 28, 1827, as cited by: Marita Mathijsen, "Zondige bewegingen," https://maritamathijsen.wordpress. com/2016/01/29/zondige-bewegingen, published 29 January 2017, accessed 30 January 2017.

38 'onzedelijk wanbedryf', 'zedelijk bederf'. Autobiography H.J. Koenen, Special Collections of the University of Amsterdam, ref. nr. RA A13, map 2, f.1.

39 Ibidem, f.157.

40 F.A. Hartsen, Nederlandsche toestanden. Uit het leven van een lijder, edited by Nop Maas, Hilversum: Verloren, 1996, 13, 155, 209. In an earlier brochure, Over onkuisscheid. Practischphilosophische en paedagogische studie (1867) he denounced onanism as 'unhealthy' and promoted marital sex.

41 Mathijsen 2003, 45. See for other euphemisms and metaphors: Parisismen, Alphabetisch gerangschikte verzameling der eigenaardige zegswijzen van het Parijsche Argot, as cited by: Van de Schoor 2014, 202-203. See for other examples of masturbation in fin de siècle literature: Kemperink 2001, 166.

42 I thank Stefan van der Poel and Bert Overbeek for drawing my attention to Polak's diary, for providing me with the digitized version of the manuscript and for their help with the interpretation of it.

43 Wedman 1999, 18. Although Polak does not seem to have actively participated in the 'Pure Life' movement, he had friends who did (such as Jacob van Rees and Felix Ortt) with whom he discussed his ideas on sexual ethics, as he recorded in his diaries. On the 'Pure Life' movement, see: Poldervaart 2003.

44 There is discussion to what extent his eugenetic ideas were meant as a moral request or as a feasible programme. See: Vermeer 2017, 147.

45 For a more elaborate analysis of the symbols in Polak's diary in connection with the medical discourse on masturbation, see: Vermeer 2017.

46 Diary Leo Polak, Special Collections of the University of Amsterdam, ref. nr. xxx F 3, part 3, 31 March 1903.

47 'En toch, zoals ik vreesde, weg[ens] geen ontlasting, weer polluti, weer zo'n treurigtragise vermorsing, vernitiging van zo veel opperst levensbeginsel.' Diary Leo Polak, part 6, 31 January 1904.

48 ' $\mathrm{k}$ wou toch dat ik van die poll's eens geregeld 14 dagen of nu tot mijn examen b.v. vrij kon blijven; 't is voor mijn geheugen - en wat rust daar niit alles op - veel te vaak'. Diary Leo Polak, part 4, 16 April 1903. On the exhaustion of his memory as a result of pollutions, see also: Diary Leo Polak, part 10, 26 March 1905. The connection between 
masturbation and memory loss can already be found in the work of the German physician Martin Schurig, Spermatologia historico-medica, Frankfurt: Johannis Beckii, 1720.

49 This is already clear from the first page of his diary in which he looks back on the past 21 years of his life in which he did not keep a diary: '21 youth years lost because of faded memory'. ('21 jeugdjaren in macht van vervagend geheugen verloren!') Diary Leo Polak, part 1, frontpage.

50 See note 1.

51 'Waarom eigel kruisjes - in pl. v. pollutie?' Diary Leo Polak, part 3, 31 March 1903.

52 Diary Leo Polak, part 3, for example on: 8 December 1902; 11 December 1902; 15 December 1902; 18 December 1902; 19 December 1902; 5 January 1903; 6 January 1903; 14 January 1903; 15 January 1903; 16 january 1903; 17 january 1903; 19 january 1903; 22 january 1903, and so on.

53 Diary Leo Polak, part 10 (1905-1906), part 15 (1913) and part 16 (1914).

54 Diary Leo Polak, part 3, 6 January 1903.

55 'Juist 't enige wat mij nog zou kunnen deren, wat mijn geluk in de weg kan staan, dat zou ik mijzelve aandoen? Acu tetigisti.' Diary Leo Polak, part 3, 15 January 1903.

56 Diary Leo Polak, part 7, 5 May 1904; part 9, 1 February 1905; part 16, 31 December 1913.

57 'meisjesvoorstellingen 's av. en 's ocht'; 'schroom dus, je veilige Schoonheid door erecti te bederven.' Diary Leo Polak, part 6, 18 February 1904.

58 'x Donderd.22 [jan 1903] trots alle redelike voorzorg gisteravend, poll. [pollutie] Omslaan tegen ochtend, na ontwaken ingedommeld, arms [?] in slaap. — k Droom dat plotsel. voorbijkomend "meisje m. 3 borsten" oorz. [oorzaak] v. een poll. is, tot m'n ergernis.' Diary Leo Polak, 3, 22 January 1903.

59 Diary Leo Polak, part 7, 5 and 27 March 1904.

$60 \mathrm{X}$ dond. 21 , Weer een heerlijke, zachte, elegante nazomerdag; met te weinig werk. Door mug in voornacht half wakker gestoken, ergo poll., en de zwangerschapsvrees. 't Zou een fraaie oorzaakketen zijn!' Diary Leo Polak, part 18, 21 August 1917.

61 'Alles wel! (berichten in Zandv. en naar Sleeswijk, blijde verwachting).' Diary Leo Polak, part 18, 31 July 1918.

62 'In trein naar Amst., lekker verwarmd 2e kl. coupé voor ons alleen — dadel. samen van geprofiteerd als jong paartje x.' Diary Leo Polak, part 53, 12 January 1941.

63 Eveline Meijer, "Masturbatiepak moet zelfbevrediging bespreekbaar maken," Algemeen Dagblad, 26 October 2016, http://www.ad.nl/lifestyle/masturbatiepak-moet-zelfbevrediging-bespreekbaar-maken a9c6c718/, accessed 30 January 2017. 